\title{
Evaluation of Top-selling Biotechnological Medicine from 2003 to 2016 in Turkey
}

\section{Türkiye'de 2003-2016 Yılları Arasında En Çok Satılan Biyoteknolojik Ilaçların Değerlendirilmesi}

\author{
๑ Elif Hilal Vural, ๑ Esra Şafak Yılmaz, ๑ Güven Bektemür*, ๑ Ismail Mert Vural, \\ ๑ Banu Bayar, ๑ Hakkı Gürsöz \\ Turkish Medicines and Medical Devices Agency, Ankara, Turkey \\ *University of Health Sciences, Division of Health Management, Ankara, Turkey
}

\section{Abstract}

\begin{abstract}
Aim: The top 100 medicines having the highest annual average sales between the years 2006 and 2015, had exceeded one-fourth of the total pharmaceutical market's value in these years. We aimed to study the status of biotechnological medicines among these medicines and evaluate the effects of policy interventions on their sales.
\end{abstract}

Methods: Sales of all medicines on an annual average value basis were calculated. The top 100 medicines with the highest annual average sales were included in the study. Time series analysis has been used for prospective estimations.

Results: Up to 2007 biotechnological medicines had not been in the top ten medicines; it increased dramatically after 2007 and in 2016, the sales of biotechnological medicines reached to $82 \%$ in top 10 sales in Turkey. On the other hand the number of biotechnological medicines among the top 100 medicines was 4 in 2003; it reached to 27 in 2016. However the number of biotechnological medicines in the top 10 medicines was 1 in 2003 and it reached to 8 in 2016.

Conclusion: The shares of biotechnological medicines in both the total pharmaceutical market and in the group of medicines with high sales are increasing every year. New policies should be developed to ensure the stability of the reimbursement system.

Keywords: Pharmaceutical market in Turkey, medicines with high sales, biopharmaceutical medicines, policy interventions
Amaç: 2003 ve 2016 yılları arasında en yüksek yıllık satış tutarı olan 100 ilaç, bu yıllarda toplam ilaç pazar değerinin dörtte birinden fazlasını oluşturmuştur. Çalışmamızda bu ilaçlar arasında biyoteknolojik ilaçların durumunu ve satışlarını incelemeyi amaçladık.

Yöntemler: Tüm ilaçların yıllık ortalama değer esasına göre satış tutarları hesaplandı. En yüksek yıllık ortalama satışa sahip ilk 100 ilaç, araştırmaya dahil edildi. Illeriye dönük kestirim yapmak için zaman serileri analizi kullanıldı.

Bulgular: Biyoteknolojik ilaçlar, 2007 yılına kadar en yüksek on ilaç arasında yer almamışken, 2016 yilında biyoteknolojik ilaç satış değerinin illk 10 ilaç içinde \%82'ye ulaştığı görüldü. Ayrıca, ilk 100 ilaç içinde biyoteknolojik ilaç sayısı 2003'de 4 iken, 2016'da bu sayı 27'ye ulaşmıştır. Illk 10 ilaçta yer alan biyoteknolojik ilaçlar; 2003'te sadece 1 adet iken 2016'da ilk 10 ilacın 8'i biyoteknolojik ilaçtır.

Sonuç: Biyoteknolojik ilaçların hem toplam ilaç piyasasında hem de yüksek miktarda satılan ilaç grubunda payı her yıl artmaktadır. Geri ödeme sisteminin sürdürülebilirliğini sağlamak için bu grup ilaçlar için yeni politikalar üretilmelidir.

Anahtar Sözcükler: Türkiye'de ilaç pazarı, yüksek miktarda satış ilaçları, biyoteknolojik ilaçlar, sağlık politikası
Address for Correspondence/Yazışma Adresi: Elif Hilal Vural Turkish Medicines and Medical Devices Agency, Ankara, Turkey E-mail: ehvural@sgk.gov.tr ORCID ID: orcid.org/0000-0003-1309-6006

Received/Geliş Tarihi: 01 August 2018 Accepted/Kabul Tarihi: 13 September 2018

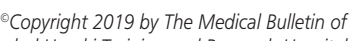
istanbul Haseki Training and Research Hospital The Medical Bulletin of Haseki published by Galenos Yayinevi.

${ }^{\circledR}$ Telif Hakkı 2019 İstanbul Haseki Eğitim ve Araştırma Hastanesi Haseki Tıp Bülteni, Galenos Yayınevi tarafindan yayılanmıştır. 


\section{Introduction}

In 2011, World Medicine Report of the World Health Organization stated that the disease burden of many countries had shifted from acute to chronic diseases (1). This has affected both the supply and use of medicines. The pharmaceutical industry is one of the largest industries in the world, and Turkey is classified among the developing countries with regard to pharmaceutical industry. Turkey is the 16th largest pharmaceutical market in the world $(2,3)$. The Turkish pharmaceutical market doubled between 2004 and 2010 on a value basis, and this growth is in accordance with the growth rate of the world pharmaceutical market.

Licensing, pricing, auditing and regulating activities are governed by the Turkish Medicine and Medical Devices Agency (TMMDA), and reimbursement is done through Social Security Institution (SSI). Reimbursement decisions in SSI are made by commissions which are composed of representatives from the relevant ministries (Ministry of Health, Ministry of Finance, Ministry of Development and Undersecretary of the Treasury). The retail sale prices of medicines are determined by the TMMDA through an external reference pricing system, and the reimbursement prices are determined by the SSI. Reimbursement prices are determined by taking various discount rates into consideration.

The multilateral structure of the pharmaceutical market has caused it to be subjected to arrangement/intervention in many countries of the world (4).

In Turkey, there have been many developments which affected the pharmaceutical market and also facilitated the access to medicine in conjunction with the Program of Transformation in Health (2003) and the Social Security Reform (2006) including implementation of the reference pricing system in 2004, implementation of the Family Medicine System firstly in pilot provinces in 2005 and all provinces in 2010; establishing SSI in 2006, establishing Reimbursement Commission within SSI in 2007; compulsion of reimbursement application file in 2008. Also, there were several public interventions from 2009 to 2012, including retail sales price cuts, additional reimbursement discounts in 2009 and 2011 and a national budget implementation on pharmaceuticals from 2010 to 2012.

The term bioeconomy refers to all economic activities derived from scientific and research activities focused on biotechnology. The health area is one of the most important branches of bioeconomy. Biopharmaceuticals and vaccines are bio-products in the health field (57). It is estimated that, biotechnological products will constitute $35 \%$ of chemical and industrial products, $80 \%$ of pharmaceutical and diagnostic products and
$50 \%$ of agricultural products by 2030 . In fact, currently, in the sectorial distribution of the world's research and development (R\&D) spendings pharmaceutical and biotechnology applications occupy the first place with $19.3 \%(6,7)$.

In this research, we aimed to examine the status of biotechnological medicines in the top 100 medicines that have the highest annual sales (represented one-third of the total pharmaceutical market value).

\section{Methods}

Total hospital and retail sales of all medicines from 2003 to 2016 were obtained using the IMS Health Turkey Database. K05, K06, T02, T03, V05, V06 and V07 groups in the Anatomical Therapeutic Chemical Classification System (ATC)-2 level were excluded from the study. This database was accessed in March 2017.

Sales of 2.593 brands were made in $2003 ; 2.606$ in 2004; 2.961 in 2005; 3.029 in 2006; 3.375 in 2007; 3.561 in 2008; 3.608 in 2009; 3.686 in 2010; 3.741 in $2011 ; 3.819$ in $2012 ; 3.953$ in $2013 ; 4.028$ in 2014 ; 4.117 in 2015 and 4.461 in 2016. Sales of all medicines on an annual basis were calculated, and then were listed according to sales, beginning with the medicine with the highest value. The top 100 medicines having the highest annual sales (total market share was $32.78 \%$ in 2016) were included in the study.

Medicines were classified according to the ATC classification system. The medicines were then classified according to whether or not they had been produced using biotechnological methods.

Sales figures and amounts of the top 100 medicines examined from 2003 to 2016 were grouped according to whether they were biotechnological products or not.

Time series analysis was used to estimate expenditure in the following years. The best fitting model was selected according to mean absolute error, mean absolute percentage error and root mean square error criteria. The exponential smoothing model was chosen as the best fitting model for both sub-groups.

\section{Results}

Turkish pharmaceutical market and biotechnological medicines market for the years 2003 to 2016

Annual change in ATC groups is given in Figure 1. Biotechnological drugs among the top 100 medicines according to ATC-1 classification are mostly in the groups of antineoplastic and immunomodulating agents and alimentary tract and metabolism (Figure 1).

Of the 100 medicines, 27 are imported biotechnological original products, and of those 27,13 are in the anti- 
neoplastic and immunomodulator group, and six are in alimentary tract and metabolism group.

While the total Turkish pharmaceutical market was 5.487 billion TL in 2003, this value reached 21.052 billion TL in 2016 (Figure 2). The total market grew about 3 (2.84) times between 2003 and 2016. Besides, the growth trend was negative between 2010 and 2013 .

The total market value of the top 100 medicines was 2.099 billion TL in 2003; this increased to 6.902 billion TL in 2016 (Figure 2). The top 100 medicines market growth was 228.8\% between 2003 and 2016 . Besides, between 2010 and 2013, the growth trend was negative.

\section{Biotechnological medicines in the top 100 and top 10 medicines}

The total market value of the biotechnological medicines which are in the top 100 medicines was 92.9 million TL in 2003; this increased to 2.591 billion TL in 2016. Growth rate was 269\% between 2003 and 2016. The total market value of the biotechnological medicines that are in the top 10 medicines was 36.7 million TL in 2003; this increased to 1.375 billion TL in 2016. Growth rate of this medicines were $364 \%$ between 2003 and 2016 (Figure 3).

The rate of the biotechnological medicine sales which are in the top 100 medicines was around 4\%; this had

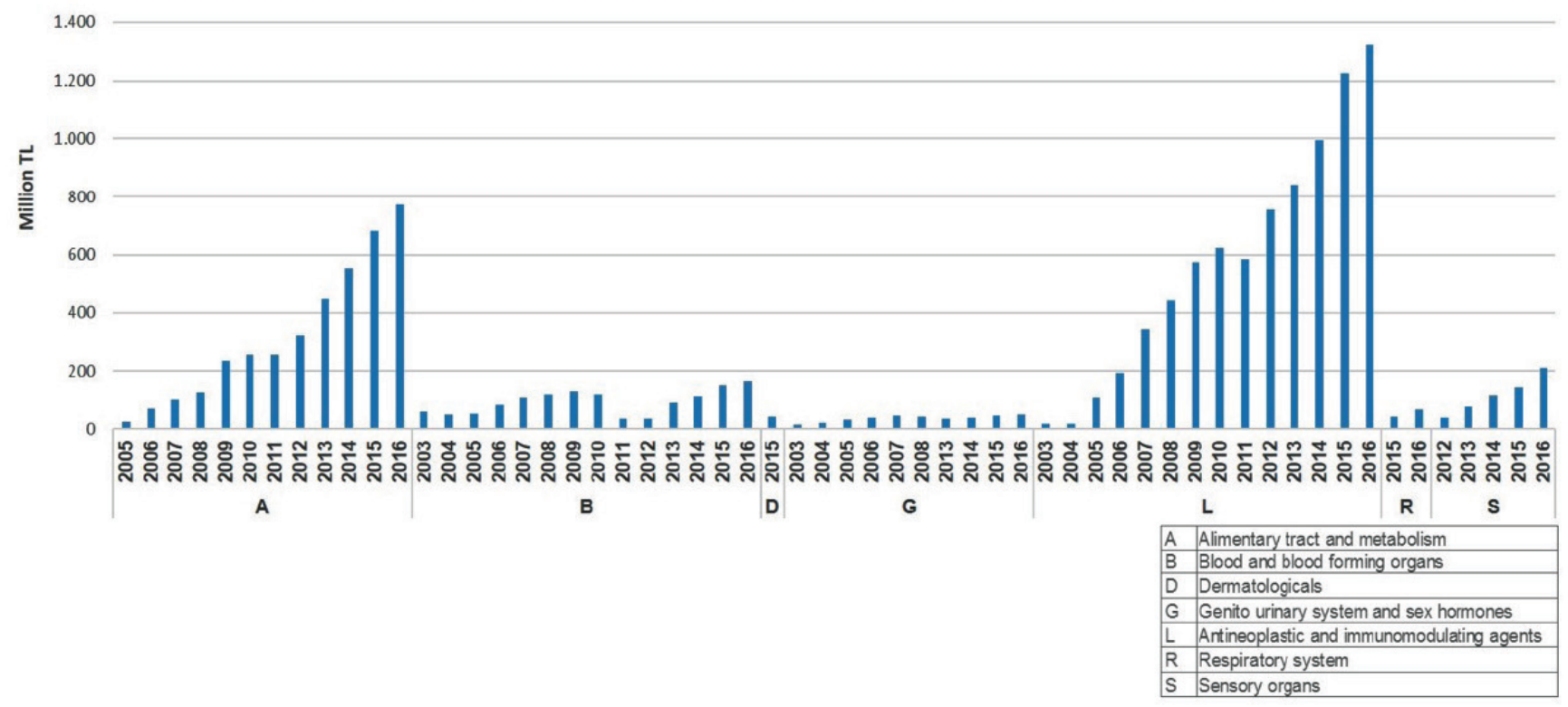

Figure 1. Annual biotechnological medicine market change in anatomical therapeutic chemical classification system groups (TL)

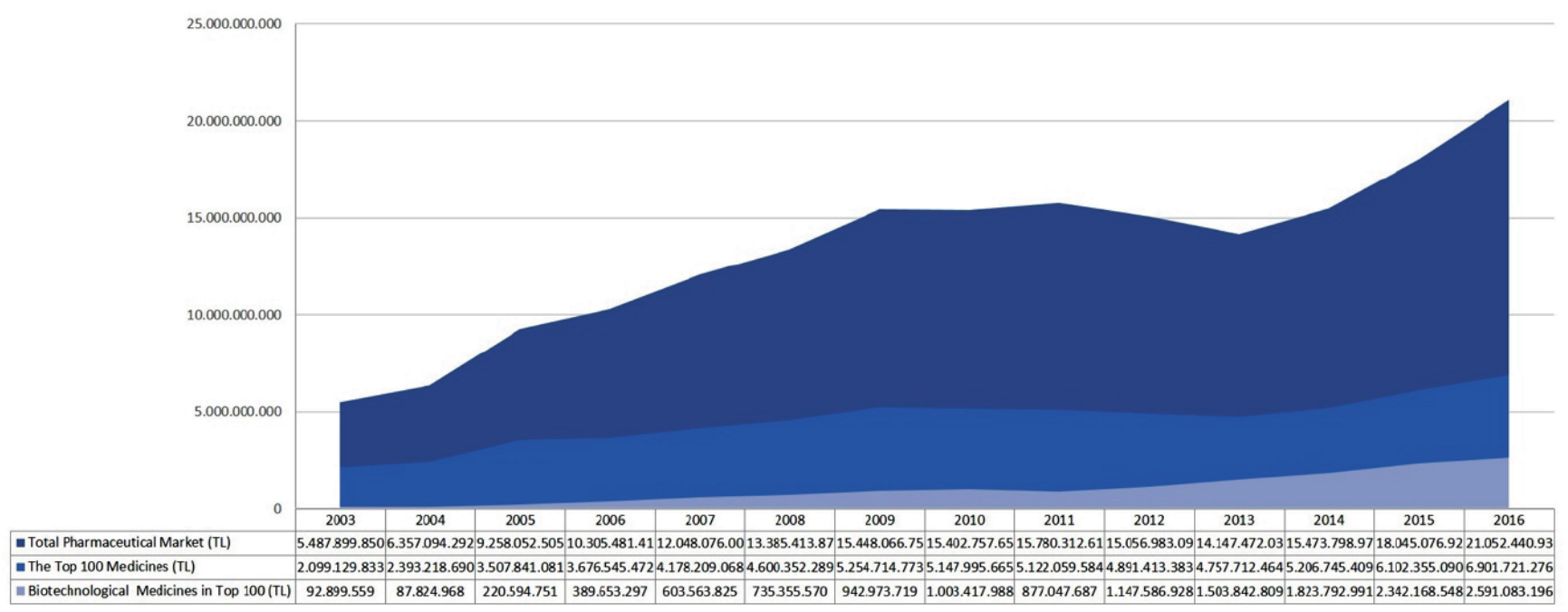

Figure 2. The change in the biotechnological medicine market over the years according to the total pharmaceutical market (TL) 
reached to $38 \%$ in 2016. Biotechnological medicines were not in the top ten medicines up to 2007; after that, it has started to increase dramatically and the ratio of the biotechnological medicine sales reached to $82 \%$ in 2016 . On the other hand the number of the biotechnological medicines which are in the top 100 medicines, was 4 in 2003 and it had reached to 27 in 2016. However, the number of biotechnological medicines which are in the top 10 medicines was 1 in 2003 and it had reached to 8 in 2016 (Figure 3).

\section{3-2016 data for the top 100 medicines and} estimation of annual sales (TL)

Sales figures for the top 100 medicines examined from 2003 to 2016, total sales and four-years estimations by drug sub-groups are as follows: Biotechnological medicine sales was estimated as 2.591.083.196 TL in 2016 and was projected to grow to nearly 3.568 billion TL by 2020 . After 2011, the biotechnological medicine annual sales growth rate increased rapidly compared to previous years. Biotechnological medicines' share of the top 100 medicine sales is projected to increase from $37.54 \%$ in 2016 to $43.31 \%$ in 2020 , whereas conventional medicine sales are projected to grow to 4.669 million TL by 2020 for those medicines included in the study group (Figure 4).

\section{Discussion}

The pharmaceutical industry is one of the largest industries worldwide. While the size of this industry was approximately 650 billion US dollars in 2006, this figure
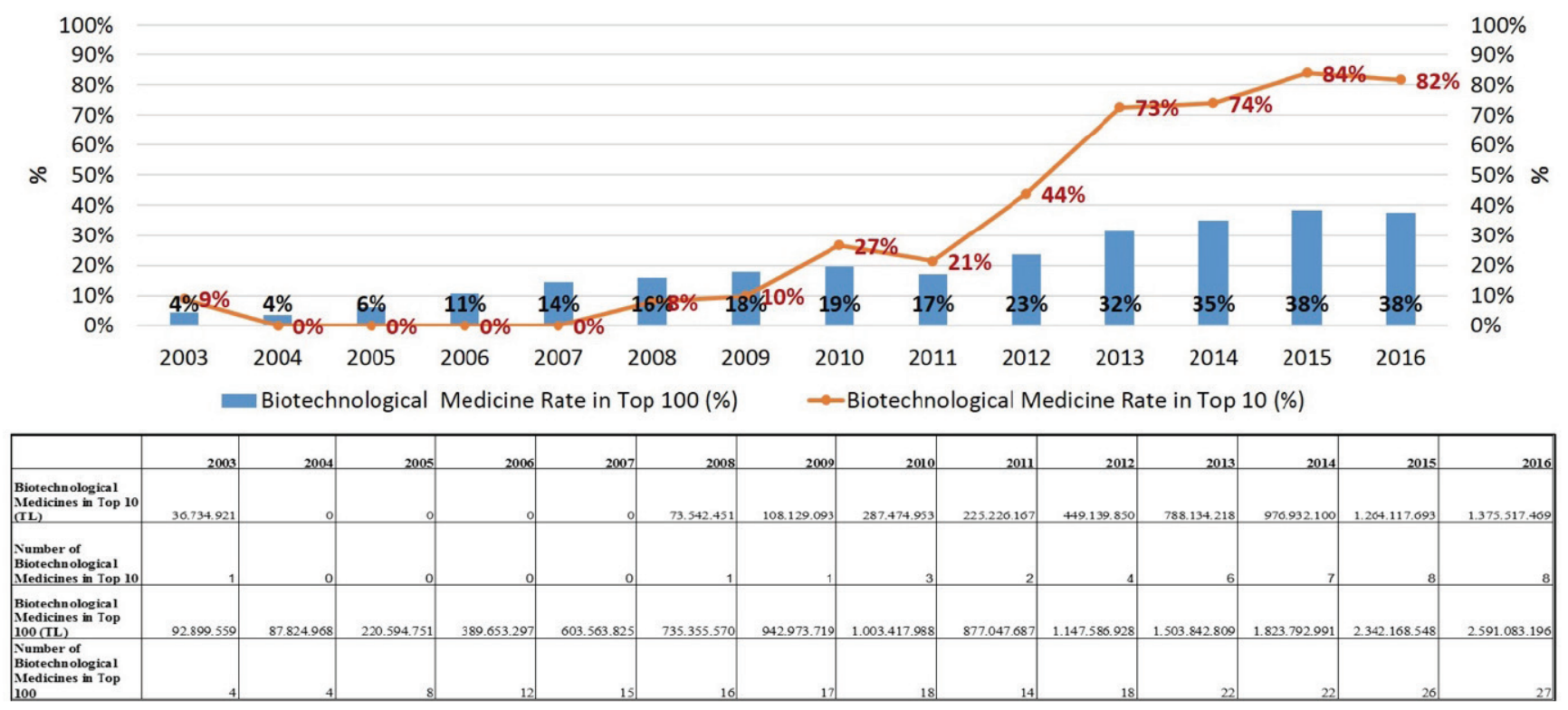

Figure 3. The rate of the biotechnological medicine sales which are in the top 100 medicines and top 10 medicines

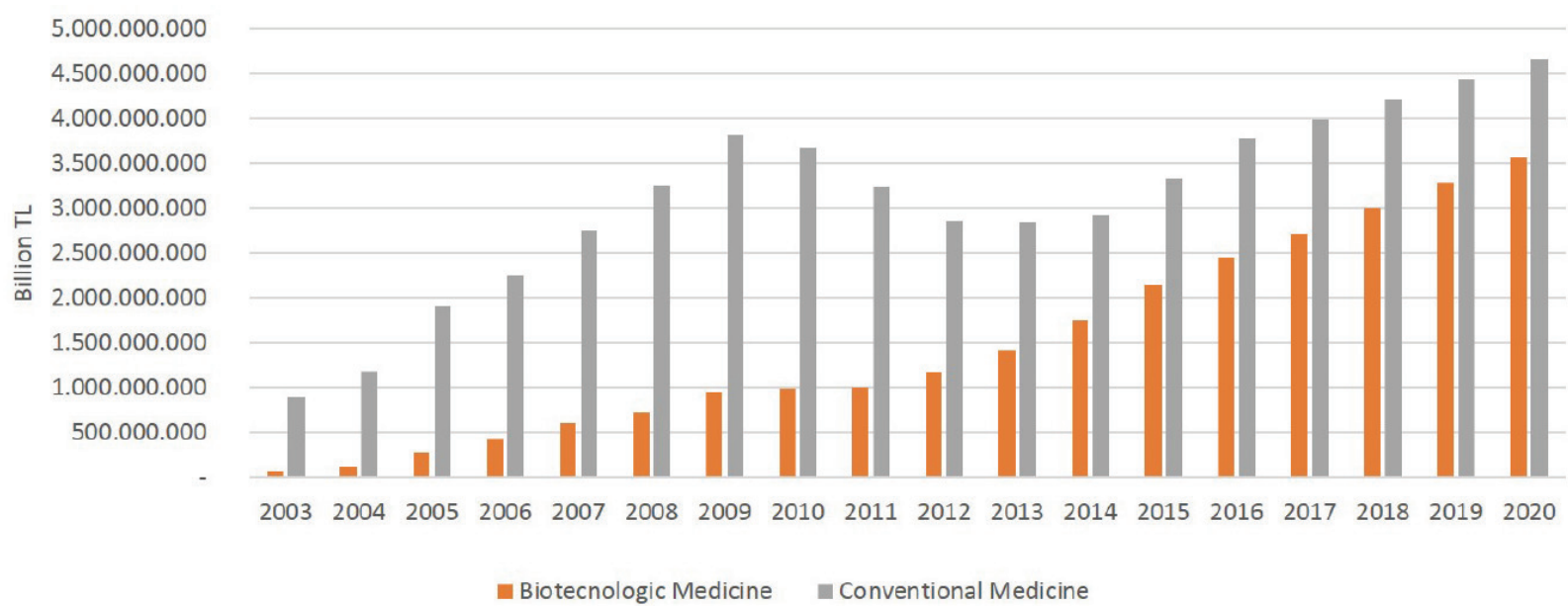

Figure 4. Annual sales of the top 100 biotechnological medicines and forecast up to 2020 (TL) 
increased to 1.057 billion dollars over the next eight years. Turkey is considered to be a developing country in the market when assessed in terms of the size of its pharmaceutical industry $(2,3)$. According to the IMS Health Database, the Turkish pharmaceutical market value was approximately 5.5 billion TL in 2003 and increased to 21 billion TL in 2016.

Biotechnology is an area where a global competition takes place because of the scarcity of resources, rapid world population growth, demographic structure of the population changes and global climate change. In many countries, economic growth through global competitiveness in biotechnology serves as an opportunity to gain influence and creates new jobs (6). The European bioeconomy market is worth about 2 trillion Euros and provides employment to approximately 21.5 million people (8).

The health area is one of the most important branches of bioeconomy. It is estimated that by 2030 , biotechnological products will constitute 35\% of chemical and industrial products, $80 \%$ of pharmaceutical and diagnostic products and $50 \%$ of agricultural products (7). In the sectorial distribution of worldwide R\&D spendings, pharmaceutical and biotechnology applications rank the first place with a combined share of $19.3 \%(6,7)$. Biopharmaceutical research companies are involved in product and vaccine development using biological processes. These represent a wide range of products, such as monoclonal antibodies, vaccines, recombinant proteins, cell therapy and gene therapy. The development of biotechnological products for different disease groups, including autoimmune disease, hematological disease, cancer, cardiovascular disease, diabetes, Parkinson's disease, asthma and dermatological disease, are emerging $(6,7)$. In our research, 13 of the 27 biotechnological medicines are in the anti-neoplastic and immunomodulatory group, and six are in alimentary tract and metabolism group in 2016. Our research found that all of the 27 biotechnological medicines of the top 100 medicines were imported products. In the Scientific American Worldview scorecard, analyzing 54 countries on their innovation potential in biotechnology through a meta-analysis, Turkey ranks at the bottom (46/54) of the list (9). Thus, it is essential to implement short-, medium- and long-term measures for developing R\&D and biotechnological ecosystem enterprises in Turkey.

Biotechnological medicine sales were estimated as $\$ 289$ billion in 2014 and are projected to grow to $\$ 445$ billion by 2019 worldwide. It was also projected that biotechnological medicines' share of the worldwide prescription medicine market and over-the-counter pharmaceutical sales will increase from 23\% in 2014 to $26 \%$ in 2019 (10). In this research, it was observed that, while the increase of $269 \%$ was realized in total sales of biotechnological medicines for the top 100 medicines from 2003 to 2016, the conventional medicine sales increased only $110 \%$. It is estimated that the sales of the biotechnological medicines included in the study group will be 3.568 billion TL for 2020, whereas the total sales of conventional medicines are predicted to be 4.669 billion TL for 2020. In this valuable group, the biotechnological medicine growth rate will be higher than the conventional medicine growth rate, as in previous years, and the biotechnological medicines' share of the top 100 medicine sales is projected to increase from $37.54 \%$ in 2015 to $43.31 \%$ in 2020.

Licensing, pricing, auditing and regulating activities are executed by the TMMDA, and reimbursement is handled by the SSI in Turkey. The retail sales prices of medicines is determined through an external reference pricing system. The countries tracked with an external reference pricing system are France, Spain, Italy, Portugal and Greece. However, if a medicine is imported, the price in the country where that medicine is produced or imported from, can be taken as a reference as well. Reimbursement decisions in the SSI are arranged by commissions comprised of representatives from the relevant ministries (Ministry of Health, Ministry of Finance, Ministry of Development and Undersecretariat of the Treasury). Reimbursement prices of medicines are regulated considering the discount rates specified in the Health Practice Communiqué (HPC). The payment list of medicines is published in the HPC and classified according to the medicine's active substance, which determines the reimbursement price (positive list). The multilateral structure of the pharmaceutical market has caused it to be subjected to arrangement/intervention in many countries of the world (4). Regulations for the market are performed in many stages, including research, production, licensing, pricing, distribution and reimbursement. To clarify, these regulations/interventions may be classified into two groups as 'supply-sided' and 'demand-sided'. While subjecting the pharmaceutical market to intervention in the form of pricing, licensing and/or regulation of distribution channels are interpreted as supply-sided interventions, determining reimbursement conditions, regulation of participation shares may be deemed demand-sided. However, this sort of intervention should be assessed as both supply-sided and demand-sided. Arrangement types may vary from one country to another. As expressed in the Competition Board Report, arrangements for economic processing for the industry have come to the forefront in countries, including Turkey, where financing health expenses is born by public institutions (4). 


\section{Conclusion}

The biotechnological medicine market is growing exponentially. According to these results, the share of biotechnological medicines in the total pharmaceutical market, as well as in the market for medicines that currently have high sales, is increasing each year. New policy strategies should be developed to ensure the sustainability of the SSI reimbursement system. In addition, our research indicates that all of the 27 biotechnological medicines in the top 100 medicines are imported from other countries. Therefore, it is essential to implement measures like investment support or prioritization in licensing in order to develop R\&D and biotechnological ecosystem enterprises in Turkey.

\section{Authorship Contributions}

Concept: E.H.V., E.Ş.Y., G.B., I.M.V., B.B., H.G. Design: E.H.V., E.S.Y., I.M.V. Data Collection and Processing: E.H.V., E.Ş.Y. Analysis or Interpretation: E.H.V., E.Ş.Y. Literatüre Search: E.H.V., E.Ş.Y. Writing: E.H.V., E.Ş.Y., G.B., I.M.V., B.B., H.G.

Conflict of Interest: No conflict of interest was declared by the authors.

Financial Disclosure: The authors declared that this study received no financial support.

\section{References}

1. Kaplan W, Mathers C. The world medicines situation global health trends: global burden of disease and pharmaceutical needs. Geneva, Switzerland: World Health Organization; 2011.

2. IMS Institute, Global Medicines Use in 2020. Available from:https://www.iqvia.com/-/media/iqvia/pdfs/institutereports/global-medicines-use-in-2020. pdf?la=uk-ua\&hash=9 68B71C0B0769A179F3A56E331C62754EEF74752; Date of Access: July 2018
3. Statistica: The Statistics Portal, Pharmaceutical market: worldwide revenue 2001-2016. Available from:http://www. statista.com/statistics/263102/pharmaceutical-marketworldwide-revenue-since-2001/ Date of Access: July 2016

4. Turkish Competition Board, Competition Report, Public interventions through the perspective of competition policy, 2013 Ankara. 6 Available from:http://www. rekabet.gov.tr/ File/ ?path=RO OT\%2fDoc uments\%2fG\%C3\% BCncel\%2fr apor2013.pdf. Date of access: March 2016

5. European Commission, Consensus Information Paper 2013 What you need to know about Biosimilar Medicinal Products. https://ec.europa.eu/docsroom/document ts/8242/.../1/.../ pdf Date of access: March 2017

6. Vural EH. Türkiye ve Dünyada Biyoekonomiye Genel Bakış, Sağlık ve Insan Dergisi 2013:16-7.

7. OECD, International Futures Project. The Bioeconomy to 2030, Designing a Policy Agenda, Main Findings and Policy Conclusions, Available from:https://www.oecd.org/futures/ long-termtechnologicalsocietalchallenges/42837897.pdf, Date of access: July 2017

8. European Commission, European Research Area, The Knowledge Based Bio-Economy (KBBE) in Europe: Achievements and Challenges Full Report. 14 September 2010. Available from:http://www.mercadosbiotecnologicos. com/documents/the_knowledge_based_bioeconomy_ kbbe_in_europe.pdf, Date of access: July 2018

9. Scientific American Worldview, Scientific American Worldview Scorecard 2016 Available from:http://www.saworldview. com/scorecard/the-2016-scientific-american-worldviewoverall-scores/, Date of access: July 2018

10. DTTL Life Sciences and Health Care Industry Group, Analysis of Industry Report: Group Biotechnology, IBISWorld, 2015. Available from:https://www2.deloitte.com/content/dam/ Deloitte/global/Documents/Life-Sciences-Health-Care/gxIshc-2015-life-sciences-report.pdf,Date of access: July 2018 